\title{
Raynaud's phenomenon in pediatric age
}

\author{
M Tavares ${ }^{1 *}$, A Novo $^{1}$, H Sousa ${ }^{1}$, I Silva ${ }^{2}$, I Almeida ${ }^{3}$, M Guedes $^{1}$ \\ From 18th Pediatric Rheumatology European Society (PReS) Congress \\ Bruges, Belgium. 14-18 September 2011
}

\section{Background}

Raynaud's phenomenon (RP) is characterized by changes in the color of extremities: pallor, cyanosis and erythema. It's prevalence in adults ranges between 3$20 \%$ but there are few studies in pediatric age. RP in boys or in children less than 12 years seems more associated to the secondary form.

\section{Aim}

Assessment of RP in children and adolescents referred to Centro Hospitalar Porto, in the last 11 years.

\section{Methods}

Retrospective analysis of clinical files of children and adolescents in which RP was the reason for consultation. Statistic analyses: SPSS version 19.

\section{Results}

Sixty six cases $(71,2 \%$ female) met the inclusion criteria. Average age of RP onset was $12,5 \mathrm{y}$ with median duration of 3,6y. RP was associated to: erythema pernio $(34,8 \%)$, inter-phalangeal joints pain $(30.3 \%)$, hands edema $(28,8 \%)$, acrocyanosis $(18,2 \%)$, profuse sweating $(12,1 \%)$ and trophic changes of fingers pulp $(10,6 \%$.). Antinuclear antibodies (ANA) were titled in 64 patients (97\%), being positive (>1/80) in ten (15.6\%). Capillaroscopy was performed on 43 (65.2\%): 32 (74,4\%) minor changes (tortuosity and segmental enlargement), four $(9,3 \%)$ significant changes (giant capillaries, hemorrhagic and avascular areas), seven (16,3\%) normal.

Of 43 patients with complete study, five $(11,6 \%)$ had secondary RP: two with juvenile systemic sclerosis, two in characterization and a probable case of mixed connective tissue disease.

Secondary RP occurred mostly in less that 12 -yearsold child. ANA $\geq 1 / 320$ and significant changes on

${ }^{1}$ Serviço de Pediatria

Full list of author information is available at the end of the article capillaroscopy had a significant statistic relationship with secondary RP.

\section{Conclusion}

RP can occur in children and, as in adults, in most cases is primary. ANA's positivity and changes in capillary bed were predictors of secondary RP.

\section{Author details}

${ }^{1}$ Serviço de Pediatria. ${ }^{2}$ Serviço de Cirurgia Vascular. ${ }^{3}$ Serviço de Medicina Interna, Centro Hospitalar do Porto.

Published: 14 September 2011

doi:10.1186/1546-0096-9-S1-P234

Cite this article as: Tavares et al:: Raynaud's phenomenon in pediatric age. Pediatric Rheumatology 2011 9(Suppl 1):P234.

Submit your next manuscript to BioMed Central and take full advantage of:

- Convenient online submission

- Thorough peer review

- No space constraints or color figure charges

- Immediate publication on acceptance

- Inclusion in PubMed, CAS, Scopus and Google Scholar

- Research which is freely available for redistribution 